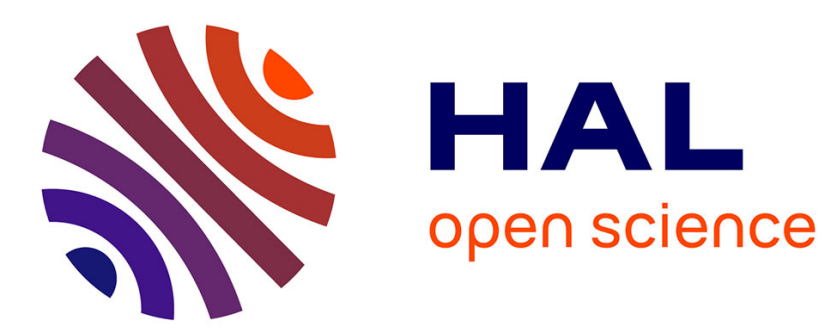

\title{
Pathogenicity factors of Meloidogyne and host plant response
}

\author{
Pierre Abad, Marie-Noelle Rosso, Bruno Favery
}

\section{To cite this version:}

Pierre Abad, Marie-Noelle Rosso, Bruno Favery. Pathogenicity factors of Meloidogyne and host plant response. Nematology, 2002, 4 (5), pp.611-614. hal-02673292

\section{HAL Id: hal-02673292 \\ https://hal.inrae.fr/hal-02673292}

Submitted on 31 May 2020

HAL is a multi-disciplinary open access archive for the deposit and dissemination of scientific research documents, whether they are published or not. The documents may come from teaching and research institutions in France or abroad, or from public or private research centers.
L'archive ouverte pluridisciplinaire HAL, est destinée au dépôt et à la diffusion de documents scientifiques de niveau recherche, publiés ou non, émanant des établissements d'enseignement et de recherche français ou étrangers, des laboratoires publics ou privés. 


\title{
Pathogenicity factors of Meloidogyne and host plant response
}

\author{
Pierre ABAD*, Marie-Noelle Rosso and Bruno FAVERY \\ INRA, Unité Interactions Plantes-Microorganismes et Santé Végétale, B.P. 2078, 06606 Antibes, France
}

Presented at

Colloque pour l'Étude de la Biodiversité des Nématodes et des Helminthes, Paris, France, 17-19 septembre 2001

Sedentary endoparasitic root-knot nematodes, genus Meloidogyne, are among nature's most successful parasites infecting more than 2000 plant species. They are a tremendous threat to crop production world-wide (Sasser, 1980; Sasser \& Freckman, 1987). Understanding the plant-nematode interactions is of major importance in order to elaborate new control strategies, since treatment of infected fields with nematicides is expensive and their use is restricted because of their toxicity to humans and the environment.

These sedentary endoparasitic nematodes interact with their hosts in a most fascinating way. They are able to induce the redifferentiation of root cells into nematode feeding sites (NFS) (Gheysen et al., 1996). Plant invasion by root-knot nematodes begins with the infective second stage juveniles (J2), which penetrate the root tip just behind the root cap, then migrate intercellularly along the vascular cylinder searching for the procambial cells that will be changed into giant feeding cells. The J2 then undergo three moults to develop into adults. Females remain sedentary, producing large egg masses and galls. Males migrate out of the plant. The mode of parasitism of rootknot nematodes is very similar to what is observed in the case of the phylogenetically closely-related cyst nematodes, which are also sedentary endoparasites infecting the root tissues. The main difference in parasitism between cyst and root-knot nematodes is that cyst nematodes migrate intracellularly through the root tissue. For both groups of nematodes, the success of parasitism thus largely depends on the efficiency with which infective juveniles penetrate and invade the root tissues. Therefore, these nematodes need some means to break down cellulose to help them migrate through root tissues.

Nematode growth and reproduction depend on the establishment of the NFS. Cytological observations indicated that these NFS are multinucleate with enlarged nuclei and nucleoli. Compared to normal cells, NFS also

\footnotetext{
*Corresponding author, e-mail: abad@antibes.inra.fr
}

(C) Koninklijke Brill NV, Leiden, 2002

Also available online - www.brill.nl show an increase in cytoplasmic density, a loss of normal vacuolation and a proliferation of cell organelles. Another characteristic feature of these structures is development of cell wall ingrowths, typical of transfer cells (Jones, 1981). These cell wall ingrowths increase the surface area of the associated membrane and thus facilitate the import of elaborated photosynthates, minerals and other metabolites.

Depending on the nematode species, the initial feeding cell develops into either a syncytium (for cyst nematodes, such as Heterodera and Globodera spp.) or a system of giant cells (for the root-knot nematodes, Meloidogyne spp.) (Jones, 1981). Syncytia result from cell fusions after cell wall dissolutions between the initial cell on which the nematode starts feeding and an increasing number of neighbouring cells. Up to 200 cells can be incorporated in a large syncytium. Conversely, giant cell formation is the result of repeated nuclear divisions of the initial feeding cell without cytokinesis. Each root-knot nematode triggers the development of five to seven giant cells, each containing as many as 100 nuclei, which have undergone vast endoreduplication (Wiggers et al., 1990). Because Meloidogyne species can induce similar giant cells in several thousand host species, they probably interact with some fundamental key steps of the plant cell cycle (Niebel et al., 1996). In addition, root-knot nematode development is accompanied by divisions of cortical cells around the NFS, giving rise to a typical root-knot or gall.

Nematodes withdraw food from NFS until the completion of their life cycle. However, it is not yet understood how these nematodes cause such alterations, but it is suspected that glandular secretions injected into plant cells interact directly or indirectly with the plant nuclear genome (Hussey, 1989).

In our laboratory, we focused on two aspects of the plant-nematode interactions, the nature of the salivary 
secretions that the nematodes inject during parasitism and the host response to the initiation of the giant cells.

\section{Molecular responses of the plant}

To identify new genes and obtain a more comprehensive view of the molecular mechanisms underlying the induction and maintenance of NFS, a promoter trapping strategy was developed with a promoterless $\beta$ glucuronidase (GUS) construct introduced randomly into the Arabidopsis genome via Agrobacterium T-DNA transformation (Bechtold et al., 1993; Bouchez et al., 1993). Using the T-DNA-tagged Arabidopsis lines obtained by INRA Versailles, we have screened 20000 lines and isolated 200 lines showing GUS expression in galls. The first results we obtained with this strategy are encouraging since we have isolated 23 genes homologous to genes involved in metabolism, signal transduction, biotic or abiotic stress responses and cytoskeleton organisation. Moreover, we have recently identified, for the first time, an upregulated nematode-responsive gene that is essential for the early steps of giant cell formation (Favery et al., 1998). Its expression pattern is similar to that of key regulators of the cell cycle, but it is not observed with cyst nematode infections. Later in NFS development, this gene is induced by both root-knot and cyst nematodes. This gene encodes a protein similar to the D-ribulose-5-phosphate 3-epimerase (RPE) (EC 5.1.3.1), a key enzyme in the reductive Calvin cycle and the oxidative pentose phosphate pathway (OPPP). Quantitative RT-PCR showed the accumulation of $R P E$ transcripts in potato as in Arabidopsis NFS. Homozygous rpe plants have a germination mutant phenotype that can be rescued in dwarf plants on sucrosesupplemented medium. OPPP may provide NADPH and sugar intermediates necessary for NFS induction and/or maintenance. During root development, this gene is also expressed in meristems and initiation sites of lateral roots. These results suggest that a common key regulator is involved in the formation of giant cells and these organs and confirm the previous cytological observations indicating that a complex redifferentiation process occurs in NFS.

Since $100 \%$ NFS promoter specificity is predicted not to exist, promoters will be deeply analysed to develop nematode resistant transgenic plants. Promoter sequences that bind nuclear proteins obtained from NFS will be identified by DNA-protein interaction analysis (gel retardation assays, foot printing, etc.). Artificial chimeric promoters (containing NRE) will be produced, fused to GUS and/or green fluorescent protein (GFP) and transformed into Arabidopsis thaliana. It will be particularly important not only to check nematode feeding site expression but also to analyse in detail expression outside the NFS under as many environmental conditions as possible. The most specific promoter(s) will be taken to drive expression of selected genes specifically in NFS. Finally, the functionality of these promoters will be tested in other plants, including tomato and rapeseed.

\section{Nematode stylet secretions}

On the nematode side, we focused our efforts on the analysis of the protein content of purified stylet secretions. In order to analyse the content of stylet secretions by 2D-gel electrophoresis, a procedure has been set up for large scale production of Meloidogyne infective juveniles and purification of stylet secretions. In this procedure, stylet secretions from the juveniles were induced by incubation in resorcinol. Analysis of these samples on 2Dgels showed the presence in the secretions of about 40 proteins of between pI 5 and 7.5. Staining the 2D-gels with Coomassie blue or silver nitrate both showed that no contaminent protein is extracted with this procedure. To our knowledge, this is the first time stylet secretions have been efficiently purified from Meloidogyne juveniles. The amount of proteins we obtained allowed direct analysis of the secretions by internal sequencing of the major proteic spots. Protein internal sequences were compared with identified sequences from databanks.

Three groups of proteins were identified. The first group is composed of proteins involved in the cytoskeleton, such as tropomyosin or troponin. The second group is composed of proteins known to have functions in metabolism regulation, such as ATP synthase $\beta$ chain or myosin regulatory light chain (MRLC). Finally, some proteins are known to have multiple functions, including cell cycle regulation, such as calreticulin and 14-3-3 protein.

From the protein sequences, degenerated oligonucleotides were designed, that allowed the cloning of the MRLC, calreticulin, 14-3-3, troponin and tropomyosin cDNAs. Studies are now underway in order to check the expression of these proteins in the pharyngeal glands of the nematode. Promising results have been obtained with calreticulin, whose expression in the subventral pharyngeal glands of second stage juveniles has been demonstrated by in situ hybridisation and immunolocalisation.

The isolation of cellulase genes in root-knot nematode represents a good example of the candidate gene strategy. By using conserved regions of nematode, fun- 
gal and bacterial endoglucanase genes, a PCR-based approach was used to identify cellulase gene in $M$. incognita. The first full-length cDNA, MI-engl, encoding a secreted $\beta$-1,4-endoglucanase was isolated and its expression was analysed during parasitism (Rosso et al., 1999). Secretion by second stage infective juveniles was demonstrated and, in order to gain understanding of the role of this cellulase in parasitism, the biochemical characterisation of the enzyme was undertaken. The enzymatic properties of MI-ENG1 were analysed in terms of physico-chemical properties, mode of action, substrate specificity and cellulose binding ability. This study provided the first extended biochemical characterisation of a family 5 endoglucanase produced by a phytoparasitic animal (Béra-Maillet et al., 2000). It appeared that MI-ENG1 shares many enzymatic properties with known endoglucanases from plants, free-living microorganisms and phytopathogens. By analysing the reaction products and by measuring the liberated reducing sugars, we have demonstrated that MI-ENG1 is an endoglucanase devoid of any exoglucanase activity. Furthermore, substrate specificity analysis showed that MI-ENG1 cleaves $\beta-1,4$ linkages but is unable to cleave $\beta-1,3$ linkages. The predicted molecular mass of MI-ENG1 is $53.4 \mathrm{kDa}$. However, zymogram and western-blot analysis together suggested that MI-ENG1 is produced as an active endoglucanase with an approximate molecular mass of $62 \mathrm{kDa}$ in total nematode homogenate and stylet secretions. This result suggests that MI-ENG1 undergoes a post-translational modification such as glycosylation when synthesised in the nematode. This hypothesis is supported by the presence of a potential $\mathrm{N}$-glycosylation site (N-P-S) in the linker region that separates the catalytic domain from the cellulose binding domain (CBD). It is assumed that such a glycosylation would protect hydrolases from proteolysis. During infestation, plant pathogens secrete cellulases that are subjected to degradation by plant proteases. Protection of cellulases from proteolysis could then play a major role in the success of pathogen development in planta. Optimal MI-ENG1 activity was observed at $\mathrm{pH} 5.0,50^{\circ} \mathrm{C}$. This $\mathrm{pH}$ condition for enzymatic activity is in accordance with the $\mathrm{pH} 5.5$ of the plant cell apoplasm. Optimal temperature and $\mathrm{pH}$ conditions revealed that MI-ENG1 is active at a large spectrum of conditions, since it retains $80 \%$ of its activity between $\mathrm{pH} 4.5$ and 6.5 and $50 \%$ of its activity between $30-60^{\circ} \mathrm{C}$. This could be related to the fact that root-knot nematodes are widespread in tropical and temperate regions. Therefore, they are subjected to various edaphic and climatic conditions and are able to par- asitise more than 200 plant species. The MI-ENG1 ability to be active at diverse $\mathrm{pH}$ and temperature conditions could reflect an ability of the enzyme to degrade host plant cellulosic materials in a large variety of environmental conditions. The MI-ENG1 endoglucanase is not significantly active against crystalline cellulose, like all the family 5 glycoside hydrolases yet characterised. Neither plant nor biotrophic phytopathogen cellulase is yet known to degrade crystalline cellulose. A large number of cellulases are not, or poorly, active on this substrate when acting separately, but an efficient degradation can be observed when glycoside hydrolases act synergistically or when they are associated in multi-enzymatic complexes (Tomme et al., 1995). This result is consistent with the assumption that plant-parasitic nematodes do not produce a large hydrolytic multi-enzyme complex, but rather a more simple and qualitative panel of hydrolytic enzymes. One peculiarity of MI-ENG1, as compared to characterised microbial or plant cellulases, is its inability to bind to cellulose in the experimental conditions tested, in spite of the presence of a cellulose-binding domain at the $\mathrm{C}$-terminal part of the enzyme.

Since then, more $\beta$-1,4-endoglucanase cDNAs highly homologous to Mi-eng1 have been evidenced in the same species in our lab. Similarly, amplifications of genomic DNA have shown that $\beta$-1,4-endoglucanase genes highly homologous to Mi-eng1 constitute a multigene family. Moreover, a second type of $\beta$-1,4-endoglucanase cDNA has been cloned from $M$. incognita. This endoglucanase cDNA, named Mi-eng2, has no linker and no CBD, and is only $38 \%$ identical to Mi-engl at the protein level. Similarly to Mi-eng1, Mi-eng 2 has been shown to be transcribed in the subventral pharyngeal glands of $M$. incognita $\mathrm{J} 2$, but this transcription seems less active than the MI-eng1.

Expressed sequence tag (EST) generation represents a very rapid and cost-effective route to approach the isolation of nematode parasitism genes. With suitable laboratory infrastructure, inexpensive EST can be quickly generated in large numbers. The most simple approach is to construct cDNA libraries from selected parasitic stages of the nematode and sequence as many random clones as possible. With database searches, EST may quickly reveal expressed genes that have an apparent role in parasitism. This has been accomplished by analysis of EST from a preparasitic J2 cDNA library of $M$. incognita (Abad et al., 2000; McCarter et al., 2000; Dautova et al., 2001).

There are literally thousands of examples of important gene discoveries that have come from. searches of EST 
data. A good example of gene discovery from EST sequencing is provided by the fact that at least 12 clones were found with homology to $\beta$-1,4-endoglucanase (Rosso et al., 1999). In addition, dbEST search showed numerous genes of potential interest including pectate lyase and polygalacturonase. The transcription of these two genes was studied by in situ hybridisation of infective stage $M$. incognita. In both cases, the transcription was localised in the pharyngeal glands of the nematode, suggesting that the pectate lyase and the polygalaturonase could be components of the stylet secretions. This study shows that the root-knot nematodes possess a range of cell wall degrading enzymes to decompose the components of the vegetal host cell wall.

Compared to plant-bacterium and plant-fungus, our knowledge of the molecular events occurring during plant-nematode interactions is still very limited. On the nematode side, efforts towards the identification of saliva components have started and should lead to a formal proof of their importance in feeding cell induction. Plant genes have been identified as being responsive to nematode infection. These genes are not only giving insight into infection process, but are also providing promoters that are useful for the design of novel resistance strategies.

\section{References}

Abad, P., Castagnone-Sereno, P. \& Rosso, M.N. (2000). Root-knot nematode EST project. Nematology 2, 740. [Abstr.]

Bechtold, N., Elis, J. \& Pelletier, G. (1993). In planta Agrobacterium mediated gene transfer by infiltration of adult Arabidopsis thaliana. Comptes Rendus de l'Académie des Sciences, Paris, 316, 1194-1199.

Béra-Maillet, C., Arthaud, A., Abad, P. \& Rosso, M.N. (2000). Biochemical characterization of MI-ENG1, a family 5 endoglucanase secreted by the root-knot nematode Meloidogyne incognita. European Journal of Biochemistry 267, 3255-3263.

Bouchez, D., Camilleri, C. \& Caboche, M. (1993). A binary vector based on Basta resistance for in planta transformation of Arabidopsis thaliana. Comptes Rendus de l'Académie des Sciences, Paris, 316, 1188-1193.
Dautova, M., Rosso, M.N., ABad, P., Gommers, F., BAKKER, J. \& SMANT, G. (2001). Single pass cDNA sequencing - a powerful tool to analyse gene expression in preparasitic juveniles of the southern root-knot nematode Meloidogyne incognita. Nematology 3, 129-139.

FAvery B., Lecomte, P., Gil, N., Bechtold, N., Bouchez, D., Dalmasso, D. \& ABAD, P. (1998). RPE, a plant gene involved in early developmental steps of nematode feeding cells. EMBO Journal 17, 6799-6811.

Gheysen, G., VAN DER Eychen, W., BARThels, N., Karimi, M. \& Van Montagu, M. (1996). The exploitation of nematode-responsive plant genes in novel nematode control methods. Pesticide Science 47, 95-101.

HuSSEY, R.S. (1989). Disease-inducing secretions of plantparasitic nematodes. Annual Review of Phytopathology 27, 123-141.

JONES, M.G.K. (1981). Host cell responses to endoparasitic nematode attack: structure and function of giant cells and syncytia. Annals of Applied Biology 97, 353-372.

MCCARTer, J., ABAD, P., Jones, J.T. \& Bird, D. (2000). Rapid gene discovery in plant parasitic nematodes via expressed sequence tags. Nematology 2, 719-731.

Niebel, A., de Almeida-Engler, J., Hemerly, A., FerReira, P., InZe, D., VAn Montagu, M. \& Gheysen, G. (1996). Induction of $c d c 2 a$ and cycAt expression in Arabidopsis thaliana during early phases of nematode-induced feeding cell formation. Plant Journal 10, 1037-1043.

Rosso, M.N., Favery, B., Piotte, C., Arthaud, L., DE BOER, J.M., HuSSEY, R.S., BAKKER, J., BAUM, T.J. \& ABAD, P. (1999). Isolation of a cDNA encoding a beta1,4-endoglucanase in the root-knot nematode Meloidogyne incognita and expression analysis during plant parasitism. Molecular Plant-Microbe Interactions 12, 585-591.

SASSER, J.N. (1980). Root-knot nematodes: a global menace to crop production. Plant Disease 64, 36-41.

SASSER, J.N. \& FRECKMAN, D.W. (1987). A world perspectve on nematology: the role of the society. In: Veech, J.A. and Dickson, D.W. (Eds). Vistas on nematology. Hyattsville, MD, USA, Society of Nematologists Inc., pp. 7-14.

TOMme P., WARren, R.A.J. \& GILKES, N.R. (1995). Cellulose hydrolysis by bacteria and fungi. Advances in Microbial Physiology 37, 1-81.

Wiggers, R.J., Starr, J.L. \& Price, H.J. (1990). DNA content and variation in chromosome number in plant cells affected by Meloidogyne incognita and M. arenaria. Phytopathology 80, 1391-1395. 